\title{
The pharmacological management of erectile dysfunction - Update 2016
}

\author{
André Marais \\ Department of Pharmacology, School of Medicine, Faculty of Health Sciences, University of Pretoria, South Africa \\ Corresponding author,email:dramarais@gmail.com / andre.marais@up.ac.za
}

\begin{abstract}
Erectile dysfunction (ED) is a trivial condition with a prevailing incidence worldwide. Phosphodiesterase-5 inhibitors (PDE-5) have revolutionised the treatment of ED and are regarded as one of the most successful drug groups in modern medicine. Generally PDE-5 inhibitors are well tolerated and the incidence of side-effects is low, however a small percentage of individuals experience headache, flushing and abdominal discomfort, resulting in discontinuation of therapy. This has led to the development of second generation PDE-5 inhibitors, displaying more selectivity for the PDE-5 enzyme thereby reducing treatment interruption and improving compliance. Several other treatment modalities, including testosterone replacement therapy and prostaglandin administration are available for resistant or failed first-line treatment. This review provides an update on the current, and future, available drugs used in the management of ED.
\end{abstract}

Keywords: cardiovascular disease, erectile dysfunction, phosphodiesterase- 5 inhibitors, prostaglandin, testosterone

\section{Introduction}

The consistent inability to achieve or maintain a penile erection sufficient for sexual intercourse is a common problem reportedly experienced by a third of men over the age of 40 years. ${ }^{1}$ Erectile dysfunction (ED) is a debilitating disease which can have profound psychological effects on personal relationships and the social well-being of the affected individual. The diagnosis and evaluation of sexual dysfunction has been well described and several validated algorithms are available in quantifying the classification and severity. The 5-item International Index of Erectile Function (IIEF) and the Sexual Health Inventory for Men questionnaires (SHIM) are commonly used in the initial assessment of ED. ${ }^{2}$ Specific sociodemographic and populationbased studies provide accurate information regarding the true prevalence of ED in different parts of the world. The wide variation in results can therefore not be used for general application. Local studies are lacking, however a recent study conducted in Durban, Kwazulu-Natal, showed more than $50 \%$ of males aged between 40-70 years experienced some degree of ED. The overall prevalence rate of ED is approximately $65 \% .{ }^{3}$ Not surprisingly, the severity and prevalence, including a decline in sexual activity, increase with age.

Several risk factors have been linked to the pathophysiology of ED. Overweight and obesity have been implicated as major causes of sexual dysfunction, which may explain the contemporary escalation of ED in younger men. Obesity-related conditions such as diabetes and hypertension are associated with endothelial damage. An evaluation of the cardiovascular status, in addition to the administration of questionnaires to men with ED may reduce mortality and improve sexual quality of life. ${ }^{4}$

\section{Mechanism of erections}

Penile tumescence and detumescence depend on the complex integration of various neurovascular signalling pathways, and the adequate function of multiple organ systems. This includes autonomic neurotransmitters (noradrenaline and serotonin), non-adrenergic-non-cholinergic neurotransmitters (neural nitric oxide and vasoactive intestinal polypeptide), and vasoactive agents produced by the vascular endothelium (prostacyclin and prostaglandin).

\section{Tumescence}

Sexual stimulation and an increase in parasympathetic activity result in nitric oxide (NO) being released from the nerve endings in the corpus cavernosum. ${ }^{5}$ In turn, NO mediates the release of cyclic guanosine monophosphate (cGMP) via the activation of the enzyme, guanylate cyclase. cGMP triggers smooth muscle relaxation, allowing increased arterial inflow and filling of the sinusoids in the corpus cavernosum. The accumulation of blood increases the intracavernosal pressure, causing passive venoocclusion and subsequent erection. Continuous smooth muscle relaxation and sustainable erection is dependent on CGMP, including the release of NO, prostaglandins and prostacyclins 
from the endothelium in response to the mechanical stretching caused by the initial increase in pressure. ${ }^{6}$

\section{Detumescence}

Detumescence occurs when cGMP is degraded to the inactive form via specific hydrolysing phosphodiesterase-5 enzymes (PDE-5), almost exclusively present in the corpus cavernosum. Ejaculation is mediated by the action of noradrenaline on the a1-adrenoreceptors, followed by contraction of the vascular and trabecular smooth muscle. The intracavernosal pressure decreases and the veno-occlusion terminates. This physiological effect of smooth muscle contraction after ejaculation results in a refractory period whereby immediate restimulation does not result in subsequent vasodilation and arterial filling.

The effect of serotonin on erectile function involves sympathetic, parasympathetic, and somatic outflow mechanisms, and is considered to exert a general inhibitory effect on male sexual behaviour.? $^{7}$

\section{Causes of erectile dysfunction}

As with most diseases, ED can be attributed to organic (physical) and non-organic (psychological) causes, but is often the result of a combination of both. ${ }^{8}$ Traditionally, physical causes refer to vasculogenic, neurogenic or endocrinological disorders (Table I) and should be differentiated from other male sexual dysfunctions, such as premature ejaculation, Peyronie's disease (anatomical causes) and disorders of orgasm. The absence of morning erections, muscle pain and cramps relieved by rest and numbness in the saddle area might indicate a physical cause and should be thoroughly investigated.

Psychogenic causes are mostly the result of depression, low self-image, relationship conflict and a stressful lifestyle, which in

Table I. Organic causes associated with erectile dysfunction

\begin{tabular}{lll}
\hline Vasculogenic causes & Neurogenic causes & Endocrinological causes \\
\hline - Atherosclerosis & - Multiple sclerosis & - Testosterone deficiency \\
- Hypertension & - Epilepsy & syndrome (TDS) \\
- Hyperlipidaemia & - Parkinson's disease & - Hypogonadism \\
- Diabetes & - Alzheimer's disease & - Hyperprolactinaemia \\
- Increased age & - Stroke & \\
- Sinusoidal fibrosis & - Spinal cord injury & \\
- Cancer & - Pelvic surgery and & \\
& prostate biopsies & \\
& - Nerve sparing radical & \\
& prostatectomy & \\
& Radiation therapy & \\
\hline
\end{tabular}

turn lead to performance anxiety and a reduction in the desire to be intimate. ED is known to be associated with certain drugs (Table II). ${ }^{9}$ Identifying the cause and assessing the risk factors may be beneficial in reducing the mortality as a result of other medical conditions, and in particular cardiovascular disease, where endothelial cell damage is the first development of the atherosclerotic process.4, 10 The famous phrase "ED equals endothelial damage, which equals early death" is taught to medical students around the world in an attempt to emphasise the importance of reducing cardiovascular risk factors, which might start off with an undiagnosed patient presenting with ED.

\section{Treatment options}

Fortunately several treatment modalities for ED are available. They consist of mechanical devices (vacuum pumps and constriction rings), surgical interventions (prosthetic penile implants, arterial reconstruction and venous blocking procedures), and pharmacological management (PDE-5 inhibitors, testosterone replacement therapy and invasive prostaglandin administration). The current approach to management aims to identify the underlying cause. Lifestyle interventions and limiting cardiovascular risk factors such as smoking, hypertension, dyslipidaemia and obesity, should be advocated. Psychotherapy alone, or in combination with psychoactive drugs and PDE-5 inhibitors, should be prescribed when depression or anxiety is the primary cause. ${ }^{11}$

First-line medical therapy with a PDE-5 inhibitor is recommended because of its efficacy, favourable side-effect profile and ease of use. Men with low serum testosterone levels should additionally receive hormonal replacement therapy, unless there are contraindications. ${ }^{12}$ Second-line treatment is reserved for men who do not respond to PDE-5 inhibitors. Available options include noninvasive vacuum devices and invasive alprostadil administration (intracavernosal injection or intraurethral suppository). ${ }^{13}$ Surgical interventions, such as prosthetic penile implantations and revascularisation procedures are mainly reserved for failed firstand second-line responses. ${ }^{14}$

\section{Phosphodiesterase-5 inhibitors}

Currently, there are four available registered PDE-5 inhibitors, i.e. sildenafil, vardenafil, tadalafil and avanafil. The latter was only approved for registration and prescription in

Table II. Drugs associated with erectile dysfunction

\begin{tabular}{|c|c|c|c|c|c|}
\hline Antihypertensives & Antiarrhythmics & Psychotropic drugs & GNRH agonists & $\begin{array}{l}\text { Anti-androgens, } \\
5 a \text {-reductase inhibitors and } \\
\text { chemotherapeutic agents }\end{array}$ & $\begin{array}{l}\text { Recreational } \\
\text { drugs }\end{array}$ \\
\hline $\begin{array}{l}\text { - Thiazide duiretics } \\
\text { - } \beta \text { blockers } \\
\text { - Calcium channel } \\
\text { blockers } \\
\text { - Methyldopa } \\
\text { - Reserpine } \\
\text { - Doxazozin }\end{array}$ & $\begin{array}{l}\text { - Digoxin } \\
\text { - Amiodarone } \\
\text { - Disopyramide }\end{array}$ & $\begin{array}{l}\text { - } T C A \text { 's } \\
\text { - SSRI's } \\
\text { - Phenothiazines } \\
\text { - Butyrophenones }\end{array}$ & $\begin{array}{l}\text { - Leuprolide } \\
\text { - Goserelin }\end{array}$ & $\begin{array}{l}\text { - Cyclophosphamide } \\
\text { - Flutamide } \\
\text { - Ketoconazole } \\
\text { - Spirinolactone } \\
\text { - Cimetidine } \\
\text { - Cyproterone } \\
\text { - Finasteride } \\
\text { - Dutasteride }\end{array}$ & $\begin{array}{l}\text { - Marijuana } \\
\text { - Opiates } \\
\text { - Cocaine } \\
\text { - Nicotine } \\
\text { - Alcohol }\end{array}$ \\
\hline
\end{tabular}


the USA from 2012, and in Europe, Australia and New Zealand from 2013. South African registration was still pending at the time of submission of this article.

PDE-5 inhibitors share a similar mechanism of action and general side-effect profile. However individual agents have distinct pharmacokinetic and pharmacodynamic properties, resulting in varying efficacies. These subtle differences facilitate tailoring of sexual therapy according to the patient's needs. ${ }^{15}$ PDE-5 inhibitors do not cause tumescence in the absence of sufficient sexual arousal and stimulation, but cause a marked reduction in the post-ejaculatory refractory time. However a decrease in detumescence is achieved by inhibiting the PDE5 enzyme, thereby effectively increasing the intracavernosal cGMP responsible for NO-induced smooth muscle relaxation and expansion in blood flow. The result is an increase in the number, strength and duration of erections. PDE-5 inhibitors are contraindicated in men receiving nitrate therapy, and should be used cautiously in combination with alpha-adrenergic blockers because of the risk of life-threatening hypotension. Common side-effects include headache, flushing, dyspepsia and nasal congestion. ${ }^{16}$ In general, all PDE-5 inhibitors appear to be safe in men $>65$ years of age, although not specifically indicated as such. PDE-5 inhibitors are highly plasma protein bound (90$95 \%$ ) therefore overdose should be managed with renal dialysis to accelerate the clearance.

Sildenafil

Sildenafil is the prototype PDE-5 inhibitor, and remains effective in treating mild ED, or men who do not complain of ED but display risk factors and low IIEF scores, including ED associated with Parkinson's disease. ${ }^{16}$ Sildenafil remains one of the most successful and popular drugs in the history of modern medicine. It is listed as one of the top 100 drugs in clinical pharmacology and practical prescribing. ${ }^{17}$ Sildenafil displays a dose-dependent response and approximately $69 \%$ of users reported a significant improvement in the quality of erections during the initial clinical trial period. ${ }^{18}$ Overall side-effects as listed above occur in 11-18\% of patients. ${ }^{19}$ In addition, sildenafil may cause altered vision due to the inhibition of PDE- 6 present in the retina. Renal clearance in patients $>65$ years is reduced, resulting in $90 \%$ higher plasma concentrations compared to men between 18-45 years. Six new generic formulations have been registered with the Medicines Control Council since this article's first print in August 2015.

Vardenafil

Vardenafil is comparable to sildenafil, but displays a greater potency and selectivity for the PDE-5 enzyme. It is clinically useful in treating ED associated with diabetes or nerve-sparing radical prostatectomy. Post marketing surveillance studies reported an average of $81 \%$ improvement in ED, and significantly lower occurrence of side-effects (5\%) compared to sildenafil. ${ }^{20}$ Chronic administration of vardenafil $20 \mathrm{mg}$ daily for six months normalises testosterone levels in hypogonadal men, but values return to baseline soon after discontinuation. The mechanism is still unknown and no such effect is observed in men with normal testosterone levels. ${ }^{21}$ Orally disintegrating tablet formulations have a more rapid onset of action and higher systemic exposure than conventional film coated tablets. Orally disintegrating vardenafil is not influenced by the presence of food, making it preferable for some patients who require an immediate effect. ${ }^{22}$

\section{Tadalafil}

Tadalafil has the same effectivity as that of sildenafil and vardenafil, but the clinical effects have been shown to last for up to 36 hours after administration, compared to four to five hours for other PDE-5 inhibitors. Overall patient satisfaction with regards to treatment expectation, erection hardness, ability to maintain an erection and partner satisfaction on a dose of 20 $\mathrm{mg}$ on demand, is nearly $86 \% .^{23}$ Lower doses of $5 \mathrm{mg}$ per day can be used for periods up to six months, but only $70 \%$ of these patients will have a meaningful improvement in ED symptoms. ${ }^{24}$ High dose, on-demand administration still appears to be more effective. ${ }^{4}$ Recently it has been approved by the FDA in the management of benign prostatic hyperplasia (BPH) and men with lower urinary tract symptoms (LUTS). Tadalafil is the only PDE-5 inhibitor not influenced by food or alcohol intake.

\section{Avanafil}

Avanafil is a new second generation PDE-5 inhibitor. It exhibits enhanced PDE-5 selectivity compared to the other available PDE-5 inhibitors, thereby displaying a more favourable sideeffect profile. It has a rapid onset of action, and is the only PDE-5 inhibitor specifically indicated for ED in men > 65years of age, where no dosage adjustment has to be made. ${ }^{25}$

Other second generation PDE-5 inhibitors include mirodenafil and udenafil, but none of these agents are commercially available yet. Initial clinical trial data however shows superior efficacy and limited side-effects. They appear to be safe and well-tolerated in men with both ED and hypertension or BPH/LUTS on treatment with alpha-1-blockers. ${ }^{26}$

\section{Testosterone replacement therapy}

Administering testosterone in the absence of low testosterone levels may be ineffective in treating ED and increases the risk of hepatic and prostate cancer. Testosterone replacement therapy should only be initiated in men with serum testosterone levels $\leq 12 \mathrm{nmol} / \mathrm{l}$, indicative of testosterone deficiency syndrome..$^{28}$ Low levels of testosterone in the presence of raised prolactin, abnormal follicle-stimulating hormone or luteinising hormone, thyroid-stimulating hormone, thyroxine and cortisol should be evaluated by an endocrinologist for specialist care.

There is a strong association between metabolic syndrome and testosterone deficiency syndrome. ${ }^{6}$ This necessitates the routine evaluation of testosterone levels in all patients with features of cardiovascular disease and diabetes mellitus, regardless of the presence or absence of ED. ${ }^{29}$ Long-acting testosterone undecanoate $1000 \mathrm{mg}$ [Nebido Bayer healthcare, single exit price (SEP) of R1843.21 for $1000 \mathrm{mg}$ ] may be injected four to five times per year and shows significant improvement in libido, morning erections, mood changes and depressive symptoms. Shorter-acting testosterone cypionate 200-400 mg (Depo- 
Table III. Comparative summary of currently available PDE-5 inhibitors

\begin{tabular}{|c|c|c|c|c|c|c|c|c|c|}
\hline Sildenafil & Strength & $\begin{array}{l}\text { SEP per } \\
1 \text { dose }^{*}\end{array}$ & $\begin{array}{l}\text { Maximum } \\
\text { dose } \\
\text { frequency }\end{array}$ & $\begin{array}{l}\text { Time to } \\
\text { clinical } \\
\text { effect }\end{array}$ & $\begin{array}{c}\text { Duration } \\
\text { of clinical } \\
\text { effect }\end{array}$ & $\begin{array}{l}\text { Satisfaction } \\
\text { on max dose }\end{array}$ & $\begin{array}{l}\text { Effect with } \\
\text { food }\end{array}$ & \multicolumn{2}{|c|}{$\begin{array}{l}\text { Incidence of common } \\
\text { side-effects on maximum } \\
\text { dosage }^{27}\end{array}$} \\
\hline $\begin{array}{l}\text { Avigra } \\
\text { (Pharmacia) }\end{array}$ & $\begin{array}{c}50 \mathrm{mg} \\
100 \mathrm{mg}\end{array}$ & $\begin{array}{l}\mathrm{R} 42.55 \\
\mathrm{R} 58.38\end{array}$ & $\begin{array}{c}100 \mathrm{mg} \text { per } \\
24 \mathrm{~h}\end{array}$ & $\begin{array}{c}12-37 \\
\text { minutes }\end{array}$ & 4-5 hours & $\begin{array}{l}74 \% \\
82 \%\end{array}$ & $\begin{array}{l}\text { Must take on } \\
\text { empty stomach }\end{array}$ & $\begin{array}{l}\text { Headache } \\
\text { Flushing }\end{array}$ & $\begin{array}{l}12 \% \\
10 \%\end{array}$ \\
\hline $\begin{array}{l}\text { Dynafil } \\
\text { (Pharmadynamics) }\end{array}$ & $\begin{array}{l}50 \mathrm{mg} \\
100 \mathrm{mg}\end{array}$ & $\begin{array}{l}\mathrm{R} 37.77 \\
\mathrm{R} 51.80\end{array}$ & & $\begin{array}{l}30-120 \\
\text { minutes }\end{array}$ & & N/A & $\begin{array}{l}\text { Fat and } \\
\text { alcohol reduce } \\
\text { absorption by }\end{array}$ & $\begin{array}{l}\text { Dyspepsia } \\
\text { Nasal congestion } \\
\text { Altered vision }\end{array}$ & $\begin{array}{l}5 \% \\
2 \% \\
4 \%\end{array}$ \\
\hline $\begin{array}{l}\text { Raviag } \\
\text { (Sun Pharma) }\end{array}$ & $\begin{array}{c}50 \mathrm{mg} \\
100 \mathrm{mg}\end{array}$ & $\begin{array}{l}\text { R37.77 } \\
\text { R51.80 }\end{array}$ & & & & $\mathrm{N} / \mathrm{A}$ & $30 \%$ & Myalgia & 0 \\
\hline $\begin{array}{l}\text { Sildavee } \\
\text { (Aspen) }\end{array}$ & $\begin{array}{c}25 \mathrm{mg} \\
50 \mathrm{mg} \\
100 \mathrm{mg}\end{array}$ & $\begin{array}{l}R 35.00 \\
R 64.02 \\
R 47.50\end{array}$ & & & & $\mathrm{~N} / \mathrm{A}$ & & & \\
\hline $\begin{array}{l}\text { Sildenafil Cipla } \\
\text { (Cipla Medpro) }\end{array}$ & $50 \mathrm{mg}$ & R15.54 & & & & $\mathrm{N} / \mathrm{A}$ & & & \\
\hline $\begin{array}{l}\text { Sildojub } \\
\text { (LeBasi Pharma) }\end{array}$ & $\begin{array}{c}50 \mathrm{mg} \\
100 \mathrm{mg}\end{array}$ & $\begin{array}{l}R 28.00 \\
R 35.00\end{array}$ & & & & $\mathrm{~N} / \mathrm{A}$ & & & \\
\hline $\begin{array}{l}\text { Silwin } \\
\text { (Winthrop) }\end{array}$ & $\begin{array}{c}50 \mathrm{mg} \\
100 \mathrm{mg}\end{array}$ & $\begin{array}{l}\text { R39.43 } \\
\text { R53.52 }\end{array}$ & & $\begin{array}{l}30-120 \\
\text { minutes }\end{array}$ & & $\mathrm{N} / \mathrm{A}$ & & & \\
\hline $\begin{array}{l}\text { Viagra } \\
\text { (Pfizer) }\end{array}$ & $\begin{array}{c}25 \mathrm{mg} \\
50 \mathrm{mg} \\
100 \mathrm{mg}\end{array}$ & $\begin{array}{l}\text { R80.74 } \\
\text { R96.34 } \\
\text { R125.76 }\end{array}$ & & $\begin{array}{l}12-37 \\
\text { minutes }\end{array}$ & & $\begin{array}{l}62 \% \\
74 \% \\
82 \%\end{array}$ & & & \\
\hline $\begin{array}{l}\text { Videna } \\
\text { (Adcock Ingram) }\end{array}$ & $\begin{array}{c}50 \mathrm{mg} \\
100 \mathrm{mg}\end{array}$ & $\begin{array}{l}\text { R36.68 } \\
\text { R49.78 }\end{array}$ & & $\begin{array}{l}30-120 \\
\text { minutes }\end{array}$ & & $\mathrm{N} / \mathrm{A}$ & & & \\
\hline $\begin{array}{l}\text { Vitrixa } \\
\text { (Lasara Traders) }\end{array}$ & $\begin{array}{c}50 \mathrm{mg} \\
100 \mathrm{mg}\end{array}$ & $\begin{array}{l}\text { R40.60 } \\
\text { R55.69 }\end{array}$ & & & & $\mathrm{N} / \mathrm{A}$ & & & \\
\hline \multicolumn{10}{|l|}{ Tadalafil } \\
\hline \multicolumn{10}{|l|}{ Vardenafil } \\
\hline $\begin{array}{l}\text { Levitra } \\
\text { (Bayer) }\end{array}$ & $\begin{array}{l}5 \mathrm{mg} \\
10 \mathrm{mg} \\
20 \mathrm{mg}\end{array}$ & $\begin{array}{l}\text { R31.03 } \\
\text { R62.06 } \\
\text { R124.07 }\end{array}$ & $\begin{array}{c}10 \mathrm{mg} \text { per } \\
24 \mathrm{~h}\end{array}$ & $15-120 \mathrm{~min}$ & $3-5$ hours & $\begin{array}{l}56 \% \\
77 \% \\
81 \%\end{array}$ & $\begin{array}{l}\text { Must take on } \\
\text { empty stomach } \\
\text { Fat and } \\
\text { alcohol reduce } \\
\text { absorption } \\
\text { No effect with } \\
\text { food but should } \\
\text { not be taken } \\
\text { with liquid }\end{array}$ & $\begin{array}{l}\text { Headache } \\
\text { Flushing } \\
\text { Dyspepsia } \\
\text { Nasal congestion } \\
\text { Altered vision } \\
\text { Myalgia }\end{array}$ & $\begin{array}{c}21 \% \\
13 \% \\
6 \% \\
17 \% \\
0 \\
0\end{array}$ \\
\hline \multicolumn{10}{|c|}{ Avanafil (not available in SA) } \\
\hline $\begin{array}{l}\text { Stendra/Spedra } \\
\text { (Vivus inc.) }\end{array}$ & $\begin{array}{l}50 \mathrm{mg} \\
100 \mathrm{mg} \\
200 \mathrm{mg}\end{array}$ & $\begin{array}{l}\text { N/A } \\
\text { N/A } \\
\text { N/A }\end{array}$ & $\begin{array}{c}200 \mathrm{mg} \text { per } \\
24 \mathrm{~h}\end{array}$ & $10-20 \mathrm{~min}$ & 6-17hours & $\begin{array}{l}47 \% \\
58 \% \\
59 \%\end{array}$ & $\begin{array}{l}\text { Absorption } \\
\text { delayed by high } \\
\text { fat meals }\end{array}$ & $\begin{array}{l}\text { Headache } \\
\text { Flushing } \\
\text { Dyspepsia } \\
\text { Nasal congestion } \\
\text { Altered vision } \\
\text { Myalgia }\end{array}$ & $\begin{array}{c}9 \% \\
4 \% \\
0 \\
2 \% \\
0 \\
0\end{array}$ \\
\hline
\end{tabular}

ODT: orally disintegrating tablet, SEP: single exit price

* Single exit price as listed in the South African Generics dictionary. Available from http://www.generic.co.za/ [Accessed June 17, 2016]

Testosterone Pfizer, SEP of R353.47 for $1000 \mathrm{mg}$ ) can be injected every three to four weeks in patients where cost is an issue, but does not provide the favourable physiological profile associated with the long-acting agent.

\section{Intracavernosal prostaglandin injections}

Alprostadil (Caverject ${ }^{\circ}$ Pfizer, SEP of R174.14 for $20 \mu \mathrm{g}$ ) is indicated as the second-line treatment when PDE-5 inhibitors fail, or patients experience an unsatisfactory response. ${ }^{9}$ Failure is regarded as the inability to attain or maintain an adequate erection on at least four successive occasions while on optimal PDE-5 inhibitor drug dosing. Alprostadil may be preferred in men with spinal cord injuries or post radical prostatectomy.

Intracavernosal injection of alprostadil blocks the inhibitory effect of the sympathetic nervous system, and acts as a direct 
smooth muscle vasodilator, causing an increase in blood flow to the penis. A predictable, sustainable erection is achieved within ten minutes, and is independent of sexual stimulation. Compliance is the largest indicator for discontinuation, and patients need adequate counselling before commencing treatment. Side-effects include pain at the site of injection, hypotension, priapism and penile fibrosis if not administered correctly.

\section{Conclusion}

ED is a multidimensional condition consisting of organic, psychological and relational components. It remains largely undertreated and treatment discontinuation is incessant. More local studies on the prevalence of ED need to be conducted in order to establish the burden of this disease on the South African population. Healthcare providers need to be familiar with all of the currently available treatment options. Treatment should be individualised and tailored according to the patient's specific needs. Association with an increased risk of cardiovascular disease and mortality should make physicians more vigilant and proactive with regard to the management of ED. Serum testosterone levels should be regularly checked in men with features of metabolic syndrome and ED. Stigma around the condition should be eliminated by proper education. Patients should be encouraged to report any symptoms to their healthcare provider, including primary care workers and pharmacists, who are in a position to adequately refer them to a physician. Mass media campaigns and government initiatives may improve cardiovascular mortality by creating public awareness concerning the health risks associated with ED.

\section{References}

1. Lindau ST, Schumm LP, Laumann EO, et al. A study of sexuality and health among older adults in the United States. N Engl J Med. 2007;357(8):762-74.

2. Rosen RC, Riley A, Wagner $G$, et al. The international index of erectile function (IIEF): a multidimensional scale for assessment of erectile dysfunction. Urology. 1997;49(6):822-30

3. Lockhat $Y$, Ross $A$, Ramlachan $P$, et al. The prevalence of erectile dysfunction at a primary healthcare clinic in Durban, KwaZulu-Natal. South African Family Practice. 2013;55(3):289-93.

4. Jannini EA, Sternbach N, Limoncin E; et al. Health-related characteristics and unmet needs of men with erectile dysfunction: a survey in five European countries. J Sex Med. 2014;11(1):40-50.

5. Melman A, Gingell JC. The epidemiology and pathophysiology of erectile dysfunction. J Urol. 1999;161(1):5-11.

6. Traish AM, Galoosian A. Androgens modulate endothelial function and endothelial progenitor cells in erectile physiology. Korean J Urol. 2013;54(11):721-31.

7. Bitran D, Hull EM. Pharmacological analysis of male rat sexual behavior. Neurosci Biobehav Rev. 1987;11(4):365-89.

8. Bella AJ, Lee JC, Carrier S, et al. 2015 CUA Practice guidelines for erectile dysfunction. Can Urol Assoc J. 2015;9(1-2):23-9.

9. Shamloul R, Ghanem H. Erectile dysfunction. Lancet. 2013;381(9861):153-65.
10. McCullough AR, Barada JH, Fawzy A, et al. Achieving treatment optimization with sildenafil citrate $(\operatorname{Viagra}((R)))$ in patients with erectile dysfunction. Urology. 2002;60(2B):28-38.

11. Schmidt HM, Munder $T$, Gerger $H$, et al. Combination of psychological intervention and phosphodiesterase-5 inhibitors for erectile dysfunction: A Narrative Review and Meta-Analysis. J Sex Med. 2014;11(6):1376-91.

12. Tsertsvadze A, Fink HA, Yazdi $F$, et al. Oral phosphodiesterase- 5 inhibitors and hormonal treatments for erectile dysfunction: A systematic review and meta-analysis. Ann Intern Med. 2009;151(9):650-W218.

13. Derouet H, Caspari D, Rohde V, et al. Treatment of erectile dysfunction with external vacuum devices. Andrologia. 1999;31 Suppl 1:89-94.

14. Montague DK. Penile prosthesis implantation for end-stage erectile dysfunction after radical prostatectomy. Reviews in Urology. 2005;7(Suppl 2):S51-S7.

15. Doumas M, Lazaridis A, Katsiki N, et al. PDE-5 inhibitors: Clinical Points. Curr Drug Targets. 2015;16(5):420-6.

16. Boolell M, GepiAttee $S$, Gingell JC, et al Sildenafil, a novel effective oral therapy for male erectile dysfunction. Br J Urol. 1996;78(2):257-61.

17. Hitchings A, Lonsdale D, Burrage $D$, et al. The Top 100 Drugs: Clinical pharmacology and practical prescribing: Elsevier Health Sciences; 2014.

18. Goldstein I, Lue TF, Padma-Nathan $H$, et al. Oral sildenafil in the treatment of erectile dysfunction. Sildenafil Study Group. N Engl J Med. 1998;338(20):1397-404.

19. Meuleman E, Cuzin B, Opsomer RJ; et al. A dose-escalation study to assess the efficacy and safety of sildenafil citrate in men with erectile dysfunction. BJU Int. 2001;87(1):75-81.

20. Kim CM, Kim YS, Sunwoo S; et al. Post-marketing surveillance study of the efficacy and safety of vardenafil among patients with erectile dysfunction in primary care. Int J Impot Res. 2007;19(4):393-7.

21. Santi D, Granata ARM, Guidi A; et al. Six months of daily treatment with vardenafil improves parameters of endothelial inflammation and of hypogonadism in male patients with type 2 diabetes and erectile dysfunction: a randomized, double-blind, prospective trial. Eur J Endocrinol. 2016;174(4):513-22.

22. Rajagopalan P, Mazzu A, Xia CH, et al. Effect of high-fat breakfast and moderate-fat evening meal on the pharmacokinetics of vardenafil, an oral phosphodiesterase- 5 inhibitor for the treatment of erectile dysfunction. J Clin Pharmacol. 2003;43(3):260-7.

23. Perimenis $P$, Roumeguere $T$, Heidler $H$, et al. Evaluation of patient expectations and treatment satisfaction after 1-year tadalafil therapy for erectile dysfunction: The DETECT Study. J Sex Med. 2009;6(1):257-67.

24. Oelke $M$, Shinghal $R$, Sontag $A$, et al. Time to onset of clinically meaningful improvement with tadalafil $5 \mathrm{mg}$ once daily for lower urinary tract symptoms secondary to benign prostatic hyperplasia: Analysis of data pooled from 4 pivotal, double-blind, placebo controlled studies. J Urol. 2015;193(5):1581-9.

25. Hellstrom WJG, Freier MT, Serefoglu EC, et al. moderateA phase II, single-blind, randomized, crossover evaluation of the safety and efficacy of avanafil using visual sexual stimulation in patients with mild to moderate erectile dysfunction. BJU Int. 2013;111(1):137-47.

26. Cho MC, Paick J-S. A review of the efficacy and safety of mirodenafil in the management of erectile dysfunction. Therapeutic advances in urology. 2016;8(2):100-17.

27. Corona G, Rastrelli G, Burri A, et al. The safety and efficacy of avanafil, a new 2nd generation PDE5i: comprehensive review and meta-analysis (vol 15, pg 237, 2016). Expert Opin Drug Saf. 2016;15(2):V-V.

28. Bhasin S, Cunningham GR, Hayes FJ, et al. Testosterone therapy in men with androgen deficiency syndromes: an Endocrine Society clinical practice guideline. J Clin Endocrinol Metab. 2010;95(6):2536-59.

29. Maggi M, Schulman C, Quinton R, et al. The burden of testosterone deficiency syndrome in adult men: economic and quality-of-life impact. J Sex Med. 2007;4(4 Pt 1):1056-69. 